\title{
FAKTOR-FAKTOR YANG BERPENGARUH TERHADAP PRODUKTIVITAS USAHATANI PADI DI LAHAN SAWAH IRIGASI PEDESAAN (Suatu Kasus Di Desa Gunungsari Kecamatan Sadananya Kabupaten Ciamis)
}

\author{
LISMAWATI $^{{ }^{*}}$, TRISNA INSAN NOOR ${ }^{2}$, AGUS YUNIAWAN ISYANTO ${ }^{1}$ \\ ${ }^{1}$ Fakultas Pertanian, Universitas Galuh \\ ${ }^{2}$ Fakultas Pertanian, Universitas Padjadjaran \\ *E-mail: lismaw617@gmail.com
}

\begin{abstract}
ABSTRAK
Penelitian dilaksanakan dengan tujuan untuk mengetahui: (1) Tingkat produktivitas usahatani padi sawah, dan (2) Faktor-faktor yang berpengaruh terhadap produktivitas usahatani padi sawah. Penelitian dilaksanakan dengan menggunakan survey di Desa Gunungsari, Kecamatan Sadananya, Kabupaten Ciamis. Sampel diambil sebanyak 82 orang dari populasi petani sebanyak 458 orang,pengambilan sampel menggunkan rumus slovin. Dari tujuan penelitian (1) didekati dengan menggunakan produktivitas faktor total dimana tingkat produktivitas diukur dengan menggunakan TFPIP, sedangkan tujuan penelitian (2) dianalisis dengan menggunakan persamaan regresi linier bergandar dimana pendugaan parameter dilakukan dengan menggunakan SPSS 16. Hasil penelitian menunjukkan bahwa, (1) Tingkat produktivitas rata-rata yang dicapai petani usahatani padi sawah adalah 0,94 dengan minimun sebesar 0,55 dan maksimum sebesar 1,71. (2) Faktor-faktor yang berpengaruh positif dan signifikan terhadap produktivitas meliputi: ukuran keluraga, frekuensi mengikuti penyuluhan dan luas lahan, sedangkan pendidikan dan umur berpengaruh positif namun tidak signifikan, sementara pengalaman usahatani berpengaruh negatif dan tidak signifikan.
\end{abstract}

Kata kunci: usahatani padi sawah, produktivitas faktor total

\begin{abstract}
The research was carried out with the aim of knowing:(1) the level of lowland rice farming productivity, and (2) the factors that influence the productivity of lowland rice farming. The research was conducted using a survey in Gunungsari Village, Sadananya District, Ciamis Regency. The sample was taken as many as 82 people from a population of 458 farmers, the sample was taken using the Slovin formula. From the research objectives (1) it is approached using total factor productivity where the productivity level is measured using TFPIP, while the research objectives (2) were analyzed using linear regression equation bergandar where estimation parameters were performed using SPSS 16. The results showed that, (1) average productivity achieved farmer paddy rice farming is 0,94 with a minimum of 0,55 and maximum of 1,71. (2) The factors that have a positive and significant effect on productivity include: family size, frequency of attending counseling and land area, while education and age have a positive but insignificant effect, while farming experience has a negative and insignificant effect.
\end{abstract}

Keywords : rice farming, total factor productivity

\section{PENDAHULUAN}

Indonesia merupakan negara agraris dengan sebagian penduduknya bermata pencaharian sebagai petani. Sektor pertanian berkontribusi besar dalam pembanguanan ekonomi sehingga pembangunan pertanian terus dikembangkan. Tujuan pembangunan pertanian untuk meningkatkan produksi yang sekaligus meningkatkan pendapatan sehingga dapat meningkatkan taraf hidup masyarakat (Martina dan Riyadhi, 2018). 
Kegiatan usahatani padi sawah dilakukan guna penguatan ketahanan pangan dengan peningkatan produktivitas. Peningkatan produktivitas padi sawah dapat dilakukan dengan peningkatan ketersediaan dan pemanfaatan lahan serta peningkatan infrastruktur dan sarana pertanian (Kementrian Pertanian, 2015).

Kegagalan petani dalam dalam melaksanakan usahatani berupa produktivitas sebagai akibat kurang efisien dalam penggunaan faktor faktor produksi. Syverson (2011) menyatakan bahwa pengefisienan faktor-faktor produksi dalam peningkatan produktivitas sangat dibutuhkan, ditambah dengan sistem pengairan berupa jaringan irigasi di lahan sawah yang memadai sehingga air selalu tersedia.

Desa Gunungsari yang berada di Kecamatan Sadananya Kabupaten Ciamis merupakan desa dengan potensi pertanian khusunya di bidang usahatani padi sawah yang bagus. Ketersediaan sumber air dengan jaringan irigasi pedesaan dan lahan yang potensial ditanami padi sawah serta pota tanam padi-padi-padi dengan menghasilkan rata-rata produktivitas padi sawah diatas rata-rata produktivitas padi sawah Kecamatan Sadananya dan diatas rata-rata produktivitas Kabupaten Ciamis.
Faktor-faktor yang mempengaruhi produksi dan produktivitas padi sawah harus diperhatikan oleh petani, sebab peningkatan produksi mempengaruhi tingkat produktivitas yang akhirnya berimas pula terhadap pendapatan dan posisi finansial petani (Isyanto, 2014).

Dari latar belakang penelitian maka tujuan yang ingin dicapai dari penelitian untuk mengetahui: (1) Tingkat produktivitas usahatani padi dilahan sawah irigasi pedesaan di Desa Gunungsari Kecamatan Sadananya Kabupaten Ciamis. (2) Faktor-faktor yang berpengaruh terhadap produktivitas usahatani padi dilahan sawah irigasi pedesaan di Desa Gunungsari Kecamatan Sadananya Kabupaten Ciamis.

Produktivitas adalah efisiensi dalam produksi, yaitu seberapa banyak output dihasikan dari seperangkat input yang digunakan (Syverson, 2011). Coelli, et,al. (2005) menyatakan bahwa produktivitas merupakan rasio keluaran yang diproduksi terhadap masukan yang digunakan. Sedangkan menurut Sunjaya dkk. (2018), produktivitas didefinisikan sebagai rasio dari output terhadap input. Pada kasus dimana ada satu output dan satu input, maka dapat dihitung produktivitas secara mudah. Produktivitas merupakan basis dari pengukuran kinerja. Kita dapat mengukur 
produktivitas dari suatu perusahaan, tetapi kita juga dapat mengukur produktivitas dari tenaga kerja, mesin, perusahaanperusahaan, sektor industri, perekonomian nasional bahkan perekonomian global.

Ukuran produktivitas ada dua, yaitu produktivitas faktor total (simultan) dan produktivitas parsial. Produktivitas faktor total merupakan produktivitas yang mengukur semua faktor (simultan) yang digunakan dalam produksi. Pengukuran tradisional lain dari produktivitas, seperti produktivitas tenaga kerja, sering disebut sebagai produktivitas parsial (Nadiri, 1970).

\section{METODE PENELITIAN}

Penelitian ini menggunakan metode penelitian survei dengan jenis penelitian kuantitatif suatu kasus di Desa Gunungsari Kecamatan Sadananya Kabupaten Ciamis.

Teknik penarikan sampel lokasi dilakukan secara sengaja (purposive sampling). Menurut Nasehudin, dkk. 2012, teknik pengambilan sampel lokasi penelitian menggunakan purposive sampling yang berarti sampel yang diambil tidak acak atau secara sengaja dengan sengaja dipilih atas pertimbangan tertentu. Penelitian dilaksankan pada musim taman MK (Musim Kemarau) 1 tahun 2020.
Teknik penarikan sampel responden mengunakan simple random sampling. Menurut Arikunto (2010) simple random sampling adalah teknik penarikan sampel dengan cara peneliti mencampur subjeksubjek didalam populasi sehingga semua subjek dianggap sama. Petani padi sawah di Desa Gunungsari jumlah populasi sebanyak 458 orang, sebagai respnden sebanyak 82 orang dengan penarikan sampel menggunakan rumus slovin (unam, 2012) dengan rumus:

$\mathrm{n}=\frac{N}{1+N e^{2}}$

Produktivitas Faktor total, menurut Coelli et al. (2005), Total Factor Productivity (TFP) merupakan suatu usahatani dengan banyak output dan banyak input secara sederhana dilihat dari profitabilitas usahatani yang didefinisikan sebagai penerimaan (revenue) dibagi dengan biaya (cost). Jika output usahatani dinotasikan dengan q atau vektor output, harga output dengan $\mathrm{p}$ atau vektor harga output, input dengan $\mathrm{x}$ atau vektor input, dan harga input dengan $w$ sebagai vektor harga input, maka profitabilitas pada usahatani padi sawah dapat dihitung dengan menggunakan persamaan sebagai berikut:

$\pi_{1}=\frac{p_{1}{ }^{\prime} q_{1}}{w_{1}{ }^{\prime} x_{1}}=\frac{\sum_{m}^{M}={ }_{1} p_{m 1} q_{m 1}}{\sum_{k}^{K}={ }_{1} w_{1} x_{1}}$

Dimana: 
$\mathrm{q}=$ Produksi $(\mathrm{kg})$

$\mathrm{x}_{1}=$ Luas lahan (ha)

$\mathrm{x}_{2}=\operatorname{Benih}(\mathrm{kg})$

$\mathrm{x}_{3}=$ Pupuk urea $(\mathrm{kg})$

$\mathrm{x}_{4}=$ Pupuk NPK $(\mathrm{kg})$

$\mathrm{x}_{5}=$ Pupuk organik $(\mathrm{kg})$

$\mathrm{x}_{6}=$ Pestisida $(\mathrm{kg})$

$\mathrm{x}_{7}=$ Tenaga kerja (HKSP)

$\mathrm{p}=$ Harga output $(\mathrm{Rp} / \mathrm{kg})$

$\mathrm{w}=$ Harga Input $(\mathrm{Rp} / \mathrm{kg})$

Pendugaan parameter produktivitas

faktor total (Total Factor Productivity, TFP) dilakukan dengan menggunakan program TFIFP versi 1.0

Faktor-faktor yang mempengaruhi produktivitas padi sawah menggunakan analisis linier berganda dengan pendugaan parameter regresi linier berganda menggunakan program SPSS versi 16. Dengan model analisis linier berganda sebagai berikut:

$\mathrm{Y}=\mathrm{b} 0+\mathrm{b} 1 \mathrm{X}_{1}+\mathrm{b} 2 \mathrm{X}_{2}+\ldots \ldots+\mathrm{biXn}+\mathrm{e}$

Model analisis linier berganda tersebut diubah ke dalam bentuk persamaan logaritma, sehingga menjadi persamaan linear berganda sebagai berikut:

$\log \mathrm{Y}=\mathrm{bo}+\mathrm{b} 1 \log \mathrm{X}_{1}+\mathrm{b} 2 \log \mathrm{X}_{2}+$ $b 3 \log X 3+b 4 \log X 4+b 5 \log X 5+b 6$ $\log \mathrm{X} 6+\mathrm{e}$

Dimana:

$\mathrm{Y}=$ Produktivitas padi sawah (ton/ha)

$\mathrm{b} 0=$ Konstanta bi $=$ Koefisien regresi

$\mathrm{X}_{1}=$ Pendidikan (tahun)

$\mathrm{X}_{2}=\operatorname{Umur}($ tahun)

$\mathrm{X}_{3}=$ Ukuran keluarga (orang)

$\mathrm{X}_{4}=$ Pengalaman berusahatani (tahun)

$\mathrm{X}_{5}=$ Frekuensi mengikuti penyuluhan. Dummy, jika > 3 kali dalam setahun barnilai 1, jika < dari 3 kali dalam setahun bernilai $=0$

$\mathrm{X}_{6}=$ Luas lahan (ha)

$\mathrm{e}=$ Kesalahan (error term)

Uji $\mathrm{F}$ digunakan untuk mengetahui variabel bebas secara simultan tidak berpengaruh signifikan terhadap variabel terikat.

$\mathrm{H} 0: \mathrm{b} 1=\mathrm{b} 2=\mathrm{b} 3=\mathrm{b} 4=\mathrm{b} 5=\mathrm{b} 6=0$

$\mathrm{H} 1: \mathrm{b} 1 \neq \mathrm{b} 2 \neq \mathrm{b} 3 \neq \mathrm{b} 4 \neq \mathrm{b} 5 \neq \mathrm{b} 6 \neq 0$

$\mathrm{H} 0=$ Tidak terdapat pengaruh dari variabel bebas terhadap variabel terikat.

$\mathrm{H} 1$ = Terdapat pengaruh dari variabel bebas terhadap variabel terikat untuk minimal satu variabel bebas.

Kriteria pengambilan keputusan yaitu:

1. H0 ditolak dan H1 diterima jika F hit > Sig 0,05

2. H1 ditolak dan H0 diterima jika F hit < Sig 0,05

Uji t variabel bebas secara parsial tidak berpengaruh signifikan terhadap variabel terikat. Hipotesis diterima jika nilai statistik t-hitung lebih kecil atau sama dengan t-tabel Jika nilai statistik t-hitung 
lebih besar dari t-tabel, maka hipotesis ditolak yang menunjukkan bahwa variabel bebas secara parsial berpengaruh signifikan terhadap variabel terikat.

$\mathrm{H} 0$ : bi $=0$

$\mathrm{H} 1: \mathrm{bi} \neq 0$

$\mathrm{H} 0=$ Tidak terdapat pengaruh dari variabel bebas ke 1 terhadap variabel terikat.

$\mathrm{H} 1$ = Terdapat pengaruh dari variabel bebas ke 1 terhadap variabel terikat.

Kriteria pengambilan keputusan yaitu:

1. H0 ditolak dan $\mathrm{H} 1$ diterima jika $t$ hit $\leq$ Sig 0,05

2. $\mathrm{H} 1$ ditolak dan $\mathrm{H} 0$ diterima jika $t$ hit $>$ Sig 0,05

Semua data dianalisis dengan melalui uji normalitas data (Priyatno, 2011) dan asumsi klasik (Salvatore, 2005; Priyatno, 2011).

\section{HASIL DAN PEMBAHASAN}

\section{Tingkat Produktivitas Padi Sawah}

Kompetensi petani merupakan kemampuan teknis dan manajerial petani dalam mengelola usahatani padi sawah. Kompetensi petani berkaitan erat dengan tingkat produktivitas usahatani padi. Menurut Isyanto dan Nuryaman (2015) Kemampuan manajerial petani berkaitan dengan produktivitas, sehingga ada variasi produktivitas yang dicapai oleh petani. Hasil analisis tingkat produktivitas usahatani padi sawah dapat dilihat pada Tabel 1.

\section{Tabel 1. Tingkat Produktivitas Usahatani Padi Sawah}

\begin{tabular}{llll}
\hline No $\quad$ Produktivita & Petani (Orang) & $\mathbf{( \% )}$ \\
\hline $1 \quad<1,000$ & 52 & 63.41 \\
$2 \quad \geq 1,000$ & 30 & 36.59 \\
\hline Jumlah & 82 & 100 \\
\hline Produktivitas maksimum & $=1.71$ & \\
Produktivitas minimum & $=0.55$ & \\
Produktivitas rata-rata & $=0.94$ & \\
\hline
\end{tabular}

Tabel 1. Menujukan bahwa tingkat produktivitas yang dicapai petani tergolong masih rendah sehingga masih ada peluang untuk meningkatkan produksi melalui peningkatan produktivitas di tingkat petani. Peningkatan produktivitas petani dapat dilakukan dengan berbagai cara seperti, manajemen usahatani yang harus mulai dibenahi dapat dilakukan dengan sekolah lapangan, pelatihan dan penyuluhan serta motivasi petani itu sendiri dalam peningkatan produksinya. Menimbang dari tingkat produktivitas padi 
sawah ada $36,59 \%$ petani dengan tingkat produktivitas di bawah 1,00.

\section{Fakror-Faktor Yang Berpengaruhi}

\section{Terhadap Produktivitas Padi Sawah}

Faktor-faktor yang berpengaruh terhadap produktivitas dimaksudkan untuk mengetahui variabel-variabel apa saja yang mempengaruhi produktivitas usahatani padi sawah, untuk membahas produktivitas maka peneliti menggunakan enam variabel, adapun variabel tersebut diantaranya pendidikan, umur,ukuran keluarga, pengalaman usahatani, frekuensi mengikuti penyuluhan dan luas lahan. Analisis faktor-faktor yang berpengaruh terhadap produktivitas usahatani padi sawah disajikan pada Tabel 2.

Tabel 2. Faktor-faktor yang Berpengaruh Terhadap Produktivitas Usahatani Padi Sawah

\begin{tabular}{llll}
\hline Variabel & \multicolumn{1}{c}{ Nilai Parameter } & t-hit & \multicolumn{1}{c}{ Sig. } \\
\hline Pendidikan & 0,048 & 0,935 & $0,353^{\text {ns }}$ \\
Umur & 0,110 & 0,676 & $0,501^{\text {ns }}$ \\
Ukuran Keluarga & 0,154 & 1,837 & $0,070^{*}$ \\
Pengalaman Usahatani & $-0,024$ & $-0,399$ & $0,691^{\text {ns }}$ \\
Frekuensi Mengikuti Penyuluhan & 0,283 & 6,045 & $0,000^{* *}$ \\
Luas Lahan & 0,245 & 7,879 & $0,000^{* *}$ \\
Konstanta & 0,423 & 0,699 & $0,487^{* *}$ \\
$\mathrm{R}^{2}$ & 0,560 & & \\
F-hitung & $15,899^{* *}$ & & \\
\hline Keterangan
\end{tabular}

$\begin{array}{cc}\text { Keterangan: } & * * \text { : nyata pada } \alpha 5 \% \\ & *: \text { nyata pada } \alpha 10 \% \\ & \text { ns: tidak signifikan }\end{array}$

Koefisien determinasi (R2) sebesar 0,560 atau $56 \%$. Hal ini menunjukkan bahwa variabel independen yaitu pendidikan, umur, ukuran keluarga, pengalaman usahatani, frekuensi mengikuti penyuluhan dan luas lahan mampu menjelaskan sebesar $56 \%$ variasi nilai produktivitas usahatani padi dilahan sawah irigasi pedesaan di Desa Gunungsari sedangkan sisanya sebesar $44 \%$ dijelaskan oleh variabel lain yang tidak terdapat dalam model persamaan. Secara parsial faktor-faktor yang berpengaruh positif dan signifikan terhadap produktivitas meliputi: ukuran keluarga, frekuensi mengikuti penyuluhan dan luas lahan. Sedangkan faktor-faktor produktivitas yang berpengaruh positif namun tidak signifikan adalah pendidikan. Sementara varaiebl pengalaman usahatani merupakan variabel faktor-faktor produktivitas yang berpengaruh negatif dan tidak signifikan. Secara simultan semua variabel yang terdidri dari pendidikan, umur, ukuran 
keluarga, pengalaman usahatani, frekuensi mengikuti penyuluhan dan luas lahan berpengaruh secara signifikan dan tanda koefisen positif.

\section{KESIMPULAN}

1. Tingkat produktivitas rata-rata yang dicapai petani usahatani padi sawah adalah 0,94 dengan minimun sebesar 0,55 dan maksimum sebesar 1,71. Petani yang mencapai produktivitas di bawah satu sebanyak 52 orang $(63,41 \%)$. Hal ini menunjukkan tingkat produktivitas yang dicapai oleh sebagian besar petani masih rendah.

2. Faktor-faktor yang berpengaruh positif dan signifikan terhadap produktivitas antara lain ukuran keluraga, frekuensi mengikuti penyuluhan dan luas lahan, sedangkan pendidikan dan umur berpengaruh positif namun tidak signifikan, sementara pengalaman usahatani berpengaruh negatif dan tidak signifikan.

\section{SARAN}

1. Tingkat produktivitas dengan angka yang dicapai oleh petani sebagian besar di bawah satu, maka ada peluang untuk lebih meningkatkan produktivitas usahatani padi di lahan sawah irigasi pedesaan Desa Gunungsari tanpa penambahan sarana produksi.
2. Peningkatan produktivitas usahatani padi sawah dapat ditempuh dengan peningkatan frekuensi penyuluhan, sehingga diharapkan dapat meningkatkan pendapatan dan kesejahteraan petani usahatani padi di lahan sawah irigasi pedesaan Desa Gunungsari.

\section{DAFTAR PUSTAKA}

Arikunto, Suharsimi. 2010. Prosedur Penelitian Suatu pendekatan Praktek. Jakarta: Rineka Cipta.

Coelli, T., Rao, D.S.P., dan Battese, G.E. 2005. An Introduction to Efficieny and Productivity Analysis. BostonDordrechtLondon: Kluwer Academic Publishers.

Isyanto, A.Y. dan Nuryaman, H. 2014. Kajian Produktivitas Usaha Penggemukan Sapi Potong di Kabupaten Ciamis. Prosiding Seminar Nasional Hasil Penelitian Sosial Ekonomi Pertanian. Yogyakarta.

Kementerian Pertanian. 2015. Rencana Strategis Kementrian Pertanian tahun 2015 - 2019. Sekretariat Jendral Biro Perencanaan, Jakarta.

Martina dan Riyandhi, P. 2018. Analisis Tingkat Kesejahteraan Petani Padi Sawah di Kabupaten Aceh Utara. Agrifo. 3(2):27-34.

Nasehudin, Toto Syatori dan Gozali, Nanang. 2012. Metode Penelitian Kuantitatif. Bandung: Pustaka Setia.

Nadiri, M.I. 1970. Some approaches to the theory and measurement of total factor productivity: a survey. Journal of Economic Literature VIII(4): 1137-1177. 
Priyatno, Duwi. 2011, Buku Saku Analisis Statistik Data SPSS, Mediakom, Yogyakarta.

Soekartawi. 2003. Prinsip Ekonomi Pertanian. Jakarta: Rajawali Press.

Sujaya, D. H., Hardiyanto, T. dan Agus, Y.I. 2018. Faktor-Faktor Yang Berpengaruh Terhadap Produktivitas Usahatani Mina Padi Di Kota Tasikmalaya. Jurnal Pemikiran
Masyarakat Ilmiah Berwawasan Agribisnis 4(1): 25-39.

Syverson, C. 2011. What determines productivity? Journal of Economic Literature, 49 (2): 326-365.

Unam, J.M. 2012. Materials management for business success: the case of the nigerian bottling company plc. International Journal of Economics and Management Sciences 1(7): 5056 